\title{
NUTRIGENOMICS AND ITS APPLICATION IN PALM OIL NUTRITION AND HEALTH RESEARCH
}

\section{INDU JAGANATH*}

\begin{abstract}
Latest research reveals that phytonutrients are capable of altering gene expression through acting on complex interactions in various biochemical and cellular pathways. This interactive interplay between phytonutrients and gene expression has given birth to a new field of frontier science known as nutrigenomics. Nutrigenomics allows for deeper understanding of the mechanism of action of phytonutrients on health whether acting in silo or synergistically as a complex mixture. Through this new field of research, scientists have now affirmed that the food contains many biological active substances which affect gene expression and is capable of shifting the balance between health and disease states.

One of the richest sources of phytonutrients can be found in palm oil (Elaeis guineensis). Palm oil, other than containing fatty acids, it is also endowed with a wide range of health benefiting phytonutrients such as tocols, carotenoids, polyphenols, phytosterols and coenzyme $Q_{10}$. In this review, concerted efforts will be made to summarise recent studies on the health benefits and the molecular mode of action of these dietary compounds found in palm oil. Further efforts will be made to exemplify how nutrigenomics through its comprehensive scientific validations can act as a catalyst to move palm oil up the agriculture value chain.
\end{abstract}

Keywords: nutrigenomics, palm oil, dietary chemicals.

Date received: 23 July 2015; Sent for revision: 8 December 2015; Received in final form: 15 April 2016; Accepted: 29 August 2016.

\section{INTRODUCTION}

The discovery of the double helix structure of DNA by Watson and Creek in 1953 represents the dawn of a new field of science. Since then, massive amounts of valuable molecular information has been acquired. Other than just transferring traits from parents to offspring, DNA was found to be responsible for all cellular processes such as regulation and synthesis of important proteins responsible for the production of hormones, receptors, signalling molecules, etc.

\footnotetext{
Director General Office, Malaysian Agricultural Research and Development Institute (MARDI) Headquarters, Persiaran MARDI-UPM, 43400 UPM Serdang, Selangor, Malaysia.

E-mail: indu@mardi.gov.my
}

However, in 2003, one of the biggest breakthroughs in the history of mankind was achieved when the human genome was decoded. This new wave of scientific revolution allowed scientists to have a deeper understanding on cellular processes occurring in our body, including the flow of genetic information from gene expression to protein and metabolite synthesis and degradation (Frazer, 2012). Concurrent with the decoding of the human genome, frontier molecular techniques were developed to measure the expression of thousands of genes or proteins simultaneously. This advancement from studying single genes to studying thousands of genes in one experiment yielded extensive and comprehensive information in many areas of research, including nutrition-related research (Mutch et al., 2005). 
Various research reports reveal that almost all cellular processes can be affected by diet and lifestyle. Nutrients and bioactive components in foods are able to alter metabolic functions in complex biochemical and cellular pathways through their action on gene expression. The study of this interface between dietary chemicals and cellular/genetic processes is referred to as nutrigenomics (Kaput and Rodriguez, 2004). Ultimately, nutrigenomics is concerned with the impact of dietary components on the genome, the proteome (the sum total of all proteins), and the metabolome (the sum of all metabolites) where they play an important role in shifting the balance between health and disease states (Mead, 2007). It is important to note that this nutrientgene interaction can unfold in two directions; that is (i) how the dietary components modify gene expression (nutrigenomics), and (2) the impact of variations in gene structure of individuals on the response to dietary components (nutrigenetics). This review will focus only on the nutrigenomics aspect of the nutrient-gene interaction. Although nutrigenomics is a relatively new discipline of biotechnology, its utilisation is growing at an exponential rate. To date, a number of leading companies such as WellGene, Nestle, Danone are already employing nutrigenomics either directly or through partnerships to contribute to their positions in the wellness market. These leading companies realise that nutrigenomics offers assurances that functional claims are based on sound science that generate quantifiable results.

This review summarises recent studies carried out on the synergistic and multi-targeted actions of palm oil dietary chemicals on various cellular pathways. It will also extrapolate on how the science of nutrigenomics can be utilised to value add, diversify and propel the growth of the healthbased sector of the oil palm industry.

\section{PALM OIL DIETARY CHEMICALS AND HEALTH}

Oil palm (Elaeis guineensis), an important commodity to Malaysia's economy is also rich in dietary components. Investigations reveal that the oil, leaves and the empty fruit bunch fibre of oil palm are rich in dietary chemicals. The oil accumulates in the fleshy mesocarp and the kernel of the fruits. About $84 \%$ $\mathrm{w} / \mathrm{w}$ of the mesocarp oil is made up of palmitic (C16:0) and oleic (C18:1) acids. Palmatic acid (44\%) falls into the category of saturated fatty acid (SFA) while oleic acid (39\%) is a monounsaturated fatty acid (MUFA) (May and Nesaratnam, 2014). The remaining oil is found in the kernel, and this palm kernel oil is rich in medium chain fatty acids, mainly the lauric (C12:0) and myristic (C14:0) acids.
The high amounts of SFA, specifically palmatic acid, has raised concerns on the ability of palm oil to raise cholesterolaemia and therefore add to the risk of cardiovascular diseases. This issue was the topic of aggressive debate for some years. However, more recent investigations do not seem to support these conclusions. A sizeable and growing body of scientific evidence indicate that palm oil's effect on blood cholesterol is relatively neutral when compared to other fats and oils such as soyabean oil (oil with more PUFA and less SFA) and olive oil. This has been comprehensively outlined in a recent review by Fattore and Fanelli (2013). A number of the studies reveal that palmitic acid slightly increases both LDL- and HDL-cholesterol levels but the HDL/LDL ratio, which is a valuable predictor of cardiovascular disease risk, is relatively constant. Fattore and Fanelli (2013) also stressed that rather than the SFA content, a more important criteria that plays a crucial role in cholesterolaemia is the type of fat and the triglyceride structure. The effects of positions of the SFA on the triacylglycerol (TAG) structure on its bioactivity was further explained by May and Nesaratnam (2014). Through a number of human clinical trials and animal studies, it was hypothesised that if long chain SFA occur at the $s n-1$ and $s n-3$ (as in palm oil), their effects are either neutral or tend to lower total cholesterol.

The main MUFA fatty acid in palm oil is the oleic acid. Unlike palmatic acid where the long chain SFA is situated at $s n-1$ and $s n-2$ position, in oleic acid it is only situated in the sn-2 position (May and Nesaretnam, 2014). When absorbed into the body, oleic acid induces beneficial effects similar to that of olive oil (Choudhury et al., 1995; Voon et al., 2011). Other than SFA, palm oil also contains about $10 \%$ linoleic acid, which is an unsaturated omega- 6 fatty acid. Linoleic acid is one of the two essential fatty acids that is needed for maintaining health in our body as it is used in the biosynthesis of prostaglandins and cell membranes (Mukherjee and Mitra, 2009).

Palm oil differentiates itself from most of other oil due to the presence of a whole array of health benefiting phytonutrients which represents $1 \%$ of its weight. The most prevalent phytonutrients in palm oil are the tocols such as $\gamma$-tocotrienol, $\delta$-tocotrienol, tocopherols which constitute 600-1000 parts per million (ppm) (Mozzon et al., 2015). Others include carotenes (500 - 700 ppm), phytosterols (300-620 ppm), squalene (250-540 ppm), coenzyme $Q_{10}(10$ 80 ppm), polyphenols (40-70 ppm), phospholipids (20-100 ppm), quinones and ubiquinones, thiols, coumarins and amino acids (Goh et al., 1985; Choo et al., 2002).

Other than the oil, palm oil waste derived from the milling process which amounts to 85 million tonnes per year globally, is also rich in phenolics. 
Palm oil phenolics consist of 3-O-caffeoylshikimic acid, 4-O-caffeoylshikimic acid, 5-O-caffeoylshikimic acid, $p$-hydrobenzoic acid and protocatechuic acid (Sambanthamurthi et al., 2011b).

\section{MODE OF ACTION AND THE BIRTH OF NUTRIGENOMICS}

\section{Dietary Chemicals and Beyond Antioxidant}

A large body of literature supports that dietary chemicals protect cell constituents against oxidative damage through direct scavenging of free radicals due to their antioxidant properties. Many of these studies were carried out in vitro cell cultures or cellfree systems (Heim et al., 2002). One such example is lycopene, the principal carotenoid in tomatoes (Gerster, 1997), which is a very efficient quencher of singlet oxygen in biological systems (Di Mascio et al., 1989) and it was hypothesised that lycopene reduces cancer risk through its antioxidant function. Through utilising state-of-the-art equipment, the protective effect of dietary chemicals was shown to extend beyond their antioxidant capacity. Most dietary chemicals are modified during absorption from the small intestine, through conjugation and metabolism, and by the large intestine, mainly through the actions of the colonic microflora (Graefe et al., 2001; Mullen et al., 2004; Jaganath et al., 2005). Thus, metabolites that reach the cells and tissues are chemically, biologically and, in many instances, functionally distinct from the dietary form and such features underlay their bioactivity (Kroon et al., 2004). Another important factor that has to be taken into account is the percentage of absorption. Numerous investigations reveal that very low levels of dietary chemicals are actually absorbed and appear in the bloodstream $(<10 \mu \mathrm{M})$, and this implies that the concept of dietary chemicals functioning as hydrogen-donating antioxidants in vivo appears to be an oversimplified view of their mode of action (Halliwell et al., 2005; Williamson and Manach, 2005). It is, therefore, hypothesised that cells respond to dietary chemicals mainly through direct interactions with receptors or enzymes involved in signal transduction, or through modifying gene expressions (Williams et al., 2004). In addition, the intracellular concentrations of dietary chemicals such as polyphenols required to affect cell signalling pathways are considerably lower than those required to impact on cellular antioxidant capacity (Spencer et al., 2003; Williams et al., 2004). Similarly, Giampieri et al. (2014) demonstrated that the biological activity of phytonutrient rich strawberry extract also spreads beyond its antioxidant capacity to other pathways where they act as ligands for transcription, thus directly altering gene expression.

\section{Synergistic and Additive Mode of Action of Dietary Metabolites}

Most health benefiting extracts including those from herbs, fruits, etc. and palm oil contain a whole array of dietary chemicals which frequently interact with each other either synergistically or additively to produce a specific or multiple health benefits. Growing evidence from the various observational and epidemiological studies indicates that consumption of a complex and varied diet that is rich in dietary compounds are more superior than taking supplements for achieving good health and in reducing risk of various degenerative diseases (Liu, 2004; Mertens-Talcott et al., 2003). Clinical trials have revealed that health benefits of diets rich in phytonutrients such as in fruits and vegetables are not due to the action of any specific phytonutrient alone. The synergistic effects of a wide array of phytonutrients are needed to give a significant positive response as revealed by a recent investigation where the anti-cancer effects of carotenoids and other phytonutrients was demonstrated to reside in their combined effects. Significant anti-cancer property was exhibited by the synergistic effects of complex mixture of several carotenoids (e.g., lycopene, phytoene and phytofluene), and polyphenols (e.g., carnosic acid and curcumin). These mixtures inhibited the androgen receptor activity and activated the EpRE/ ARE system up to four-fold higher than the sum of the activities of the single ingredients (LinnewielHermoni et al., 2015).

When these array of dietary chemicals are consumed, a complex interface exists between them and their interaction with the body, making it difficult to accurately determine the exact mode of action. A simplified view is frequently presented in many past investigations where the bioactivity of each individual dietary chemical is evaluated through isolated or non-holistic studies. A more complete investigation on the whole complex interface between the 'nutritional environment' and multiple cellular pathways involved to bring about a desired outcome in disease management can be achieved through nutrigenomics To achieve this objective, nutrigenomics utilises high throughput equipment such as mass spectrometry liquid chromatography, RealTime PCR, microarray and draws upon a wide array of sciences such as nutritional science, metabolomics, transcriptomics, pharmacokinetics, and bioinfomatics. Information derived from such studies includes the identity of the major dietary chemicals in the diet; their absorption and bioavailability; effects on expression levels of disease related genes; elucidation of mode of action of the absorbed metabolites on targeted tissues are obtained. Nutrigenomics therefore challenges us to understand, in molecular detail, the 
complex interactions between the genes and dietary components in humans (Stover, 2004).

\section{Complex Mixtures of Dietary Metabolites Affect Multiple Cellular Pathways - Science of Nutrigenomics}

As the science of genomics evolves, it is apparent that the concept of 'one gene-one phenotype-one drug' hypothesis is too simplistic for management of diseases. This is because diseases are complex in nature and are regulated by multiple genes and cellular processes. Emerging therapeutic approaches now simultaneously modulate multiple targets to enhance therapeutic efficacy in the treatment of a range of disorders (Flordellis et al., 2007). In a similar context, multitargeting for diet-related diseases can also be achieved by the combination of different health benefiting phytonutrients in a single diet/ food/plant extract. This is evident through a number of nutrigenomics studies carried out to date where phytonutrients such as curcumin (Thangapazham et al., 2006), resveratrol (Jang et al., 1997), luteolin (Byun et al., 2010) were demonstrated to exert their preventive and or curative actions through acting at multiple targets in various stages of developmental process of diet-related diseases. For example in cancer, phytonutrients are able to inhibit cell proliferation, induce apoptosis, modify DNA repair, modify activity of xenobiotic-metabolising enzymes, modify activity of other enzymes and act as antioxidants (Pan and Ho, 2008). In fact, better efficacies are achieved when a wide range of phytonutrients are utilised simultaneously as observed in pomegranate (Heber, 2008), Phyllanthus sp. (Jaganath and Alizah, 2014; Lee et al., 2013), and Gynura procumbens (Mohd Waznul et al., 2014).

Nutrigenomics studies carried out at the Biotechnology Research Centre, Malaysian Agricultural Research and Development Institute (MARDI), revealed that polyphenols such as ellagitannins, phenolic acid and flavonoids in Phyllanthus sp. (dukung anak) synergistically exhibited anti-atherosclerotic properties in mice through modulating genes related to the onset of cardiovascular diseases. A total of 28 genes were significantly modified to positively affect seven different cellular pathways, namely the inflammatory, REDOX, lipid transport, macrophage entry, apoptosis, blood pressure and plaque formation (Jaganath and Alizah, 2014). In another study, Phyllanthus polyphenols also exhibited significant anti-viral properties through modulating genes involved in viral entry, viral transcription and translation regulations, cytoskeletal assembly, and cellular metabolisms (Lee et al., 2013). Yet in another study, polyherbal mixture of sambung nyawa (Gynura procumbens) and Phyllanthus watsonii, rich in derivatives of caffeoyl quinic acid and ellagitannin acted synergistically together to reduce blood sugar levels in streptozotocin-induced rat through its action on insulin signalling, adipokine pathway, glucose metabolism and glucocorticoid signalling pathway (Mohd Waznul et al., 2014). The hypothesis of multiple phytonutrients-multiple targets to improve therapeutic efficacy was further strengthened with the investigations carried out by Wang et al. (2014). Three polyphenolic preparations (grape seed extract, resveratrol, and Concord grape juice extract) with different polyphenolic compositions simultaneously and synergistically mitigated amyloid- $\beta(\mathrm{A} \beta)$ for better protection against cognitive impairments compared to individual treatments in a mouse model of Alzheimer's disease.

\section{NUTRIGENOMICS OF PALM OIL}

\section{Nutrient-gene Interaction in Palm Oil}

The hypothesis of multiple phytonutrients modulating multiple genetic and cellular pathways can also apply to palm oil as it contains wide array of different classes of dietary compounds. However, to date, limited studies have been documented that focus on the effects of palm oil (as a whole food component) on expression of diet-related genes. Some studies have been carried out by the team at the Malaysian Palm Oil Board but these investigations are restricted mainly to palm oil phenolics. Palm oil phenolics areliquors (rich in flavonoids, phenolic and hydroxyl acids) derived from oil-bearing fruit and their products where undissolved solids, oleaginous parts, colloids and higher weight molecules are removed from vegetation liquor (Sambanthamurthi et al., 2008). Investigation reveals that palm oil phenolics is able to elicit multitargeted action in vivo where it demonstrates anti-hypertensive, anti-plague, anti-arrhythmia, anti-diabetic and anti-tumour properties (Sambanthamurthi et al., 2011a). Further molecular studies indicate that the inhibition of tumour growth by palm oil phenolics occur most probably through inducing the G1/S phase arrest of the cell cycle and through down regulating genes such as Stat 3 , chemokine (C-X-C motif) and ligand 12 ( $\mathrm{Cxcl12}$ ) to reduce cancer cell invasion and proliferation (Sambanthamurthi et al., 2011a). On the other hand, its anti-diabetic properties are exhibited through modulating expression of genes in three cellular pathways, namely glucose absorption, insulin resistance and insulin secretion (Bolsinger et al., 2014). Oil palm phenolics were also found to improve cognitive and motor functions in vivo mediated through its neuroprotective and anti-inflammatory effects (Leow et al., 2013). The improvement was attributed to the up-regulation of synaptogenesis 
and neurotransmission genes as well as the down-regulation of inflammatory genes.

Other than phenolic compounds, palm oil is also rich in vitamin $\mathrm{E}$ and carotenoids. To mimic the phytonutrient profile of the palm oil, an attempt was made to determine its anti-atherosclerosis property by incorporating fat-soluble palm vitamin $\mathrm{E}$ (tocopherols and tocotrienols) to the palm oil phenolics. Palm vitamin E and oil palm phenolics individually inhibited atherosclerotic lesion development in an atherogenic rabbit model. However, when in combination, they exhibited synergism and provided better protective effects against the development of atherosclerotic lesions (Che Anishas et al., 2014). This hypothesis is also supported by the investigations by Nesaretnam et al. (1995) who demonstrated that the tocotrienolrich fraction of palm oil inhibited the proliferation of human breast cancer cells, while palm oil devoid of vitamin $\mathrm{E}$ did not protect against mammary tumourigenesis in rats. The importance of tocotrienol in diet has been emphasised in a growing number of scientific investigations. Data from numerous in vitro and in vivo studies show that tocotrienols are capable of regulating multiple cell signalling pathways such as nuclear factor- $\kappa \mathrm{B}$, signal transducer and activator of transcription (STAT) 3, death receptors, apoptosis, nuclear factor (erythroid-derived 2)-like 2 (Nrf2), hypoxiainducible factor (HIF) 1, growth factor receptor kinases, and angiogenic pathways (Kannappan et al., 2012). Many isomers of tocotrienols exist, and not all are beneficial for health but those found in palm oil such as $\alpha-, \delta$-, and $\gamma$-tocotrienols both individually and in combination have demonstrated anti-cancer properties. Its mode of action is attributed to its binding capacity to the estrogen receptor (ER) and thereby activating the expression of estrogen-responsive genes (MIC1, EGR-1 and Cathepsin D) in breast cancer cells (Nesaretnam et al., 2012).

The mesocarp of the oil palm fruit yields a deep red coloured palm oil, due to the presence of carotenoids of which alpha and beta carotenes are the most abundant (Zeb and Mehmood, 2004). A higher concentration of beta- and alpha-carotene can be found in red (virgin) palm oil. According to Sundram et al. (2003), red palm oil is the richest naturally occurring source of beta-carotene where approximately $500-800 \mathrm{mg}$ of pro-vitamin A carotenoids are obtained in $1 \mathrm{~kg}$ of oil, which is 15 times higher than the carotenoid content in carrots (weight-by-weight basis). A review by Oguntibeju et al. (2009) outlined some of the additional benefits of palm oil with higher carotenes. These include reduction in the risk of arterial thrombosis and/or atherosclerosis, inhibition of endogenous cholesterol biosynthesis, platelet aggregation, a reduction in oxidative stress and a reduction in blood pressure.
In addition, it also promotes efficient utilisation of nutrients, activates hepatic drug metabolising enzymes, facilitates the haemoglobinisation of red blood cells and improves immune function (Oguntibeju et al., 2009). Carotenoids, especially as supplements, are poorly absorbed in our body due to reasons related to food matrix. However, in red palm oil poor bioavailability is overcome as the carotenoids are already dissolved in oil. A number of intervention trials carried out supports the claim that red palm oil is efficacious in preventing vitamin A deficiency among populations at risk and can improve the vitamin A status of infants, children, and women (Rice and Burns, 2010). Bai et al. (2005) attributed the anti-inflammatory properties of betacarotene both in vitro and in vivo through its action as a potential inhibitor for redox-based NF-kappaB activation.

Coenzyme $\mathrm{Q}_{10}$ is also present in small amounts in palm oil. However, its antioxidant capacity is said to be 10 times higher compared to vitamin E (May and Nesaretnam, 2014). Coenzyme $Q_{10}$ is a small electron carrier needed in several mitochondrial biochemical pathways such as oxidative phosphorylation, $\beta$-oxidation and pyrimidine nucleotide biosynthesis. Its deficiency causes mitochondrial dysfunction and causes encephalomyopathy, ataxia and renal failure (Fernandez-Ayala, 2013). Numerous diseases such as cardiovascular disease, Parkinson's disease, muscular dystrophy, breast and other cancers, diabetes mellitus, acquired immunodeficiency syndrome (AIDS), asthma, thyroid disorders, and periodontal disease have benefited from coenzyme $\mathrm{Q}_{10}$ supplementation. The mode of action of coenzyme $\mathrm{Q}_{10}$ is believed to be mainly through its action on numerous genes involved in cell signalling, oxidative phosphorylation, in cell death and differentiation and inflammation pathways (Fernandez-Ayala et al., 2013; Schmelze et al., 2011; Groneberg, 2005).

Another bioactive compound that is present in low amounts in palm oil is squalene. Squalene is a triterpene and is vital for the synthesis of cholesterol, steroid hormones and vitamin $\mathrm{D}$ in the human body. Squalene is used as an adjuvant in vaccines, for example it is added to influenza vaccines to help stimulate the human body's immune response. Other studies indicate that squalene can effectively inhibit chemically induced skin, colon and lung tumorigenesis in rodents. The mode of action is through inhibition of Ras farnesylation modulation of carcinogen activation, and as a free radical scavenger (Auffray, 2007; Charlton-Menys and Durrington, 2007).

\section{Nutrigenomics Study on Palm Oil - The Way Forward}

The presence of the whole array of the health benefiting phytonutrients as indicated earlier 
makes palm oil a very unique and a precious food. It will be very interesting to note how these dietary components synergistically act together as a whole food component to exert their preventive and / or curative actions through acting at multiple molecular targets in the body. A hypothetical model based on previous studies is presented in Figure 1. However to validate its true efficacy, in vivonutrigenomics effects of palm oil within the frame of a healthy Malaysian diet should be carried out. Similar studies have been carried out on virgin olive oil where the gene expression of a total of 45 atherosclerosis-related gene was modified, and there was significant down-regulation of proatherogenic genes (Konstantinidou et al., 2010). In addition, the comprehensive mode of action of olive oil was elucidated in the management of atherosclerosis.

The correct dosages needed to produce a beneficial effect can sometimes be crucial in the management of diet-related diseases. For example, a number of studies reveal that low intakes of beta carotene in food are beneficial but high intakes such as in supplements may increase the risk for lung cancer in heavy smokers, asbestos workers and alcohol users (Rapola et al., 1997; Albanes et al., 1996, Keijer et al., 2005). To establish the window of benefit and obtain the correct dosage, the science of nutrigenomics can be applied to comprehensively obtain insight into the mechanism of action of the different phytonutrients such as beta carotene, phenolics and tocols in the food matrix of palm oil.

Other than comprehensively validating the efficacies of the health benefiting components in palm oil, nutrigenomics can also be utilised to promote value creation. The science of nutrigenomics allows us to design food, nutraceuticals or prescribe certain kinds of food that will enable our body to alter gene expression and reduce the expression of unfavourable genes or over-express favourable genes related to a particular disease (Jaganath and Alizah, 2014). In this context, there is immense possibilities to improve and value add palm oil to more effectively market it as a healthy vegetable oil similar or more superior to virgin olive oil. Although red (virgin) palm oil is already enriched in health benefiting components, further biofortifications or modifications of processing

\section{PALM OIL NUTRIGENOMICS}

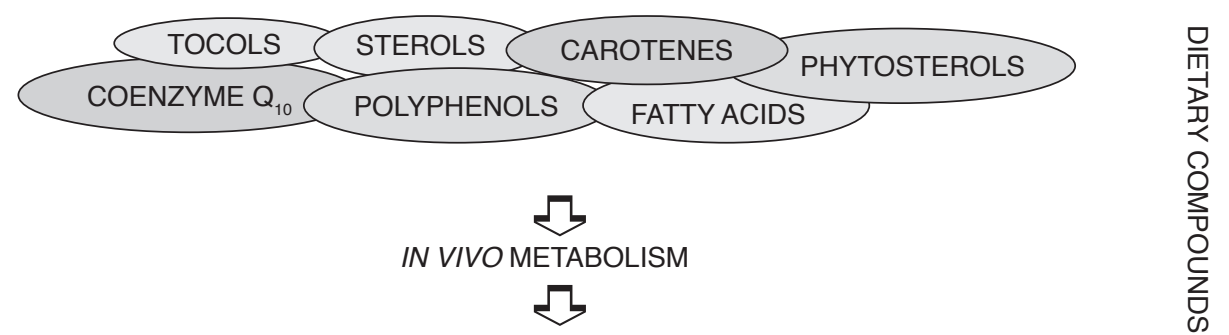

Diverse Array of Metabolites: Chemically and Structurally Different from Parent Compounds

5

SYNERGISTIC \& ADDITIVE ACTIONS OF METABOLITES ON TARGETED ORGANS AFFECTING MULTIPLE GENES AND MULTIPLE CELLULAR PATHWAYS

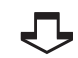

PROBALE BIOACTIVITIES \& PATHWAYS AFFECTED THROUGH MODIFICATION OF GENE EXPRESSION

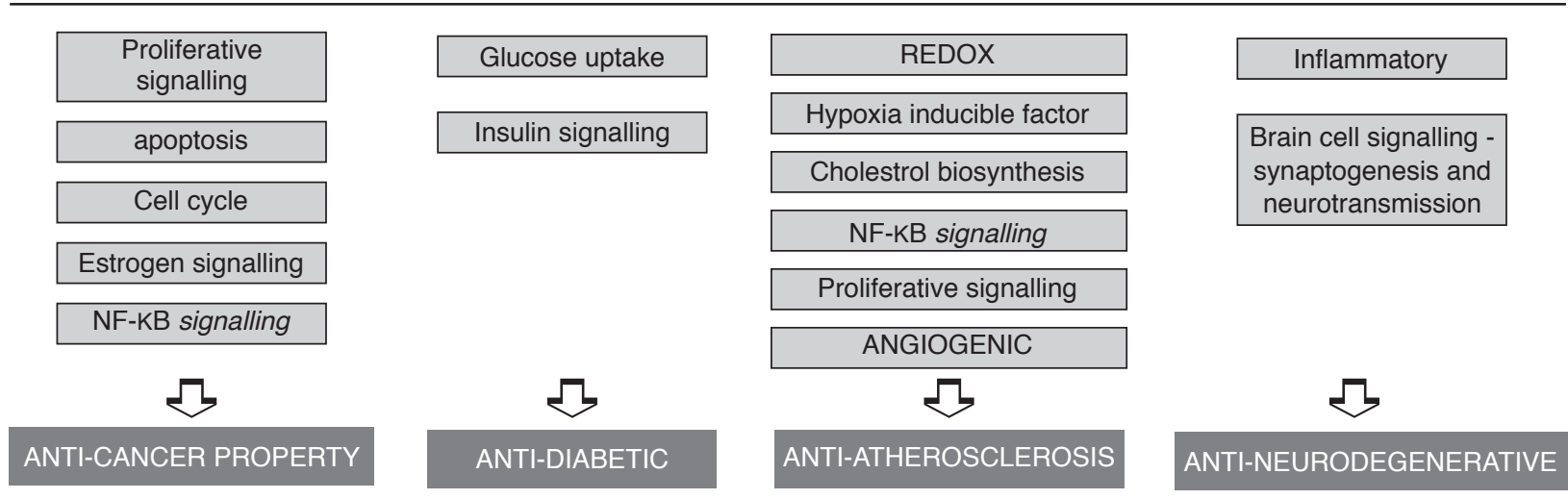

Figure 1. Hypothetical model of synergistic and multiple-targeted actions of dietary compounds in palm oil on various in vivo cellular pathways. This model is based on previous studies carried out by the following authors: Sambanthamurthi et al. (2011a); Bolsinger et al. (2014); Leow et al. (2013); Che Anishas et al. (2014); Nesaretnam et al. (2012); Oguntibeju et al. (2009). 
technique and/or even breeding techniques can be applied to maximise the composition of desirable health benefiting components in palm oil. Their products then can be tested and validated through the application of nutrigenomics. Currently, nutritionally enhanced oils are of interest to many organisations, such as Dow, DuPont, Bunge, ADM, Unilever, Monsanto, CSIRO, and BASF (Ruth and Wrick, 2005).

New upcoming areas that will enable us to have a deeper understanding and further unravel the complex interaction between genes and dietary components in palm oil would be nutrigenetics. Nutrigenomics allows us to study diet-gene interaction at the population level. However, as the science of nutrigenomics advances into nutrigenetics, specific dietary recommendations to individuals based on their genetic profile can be developed. The development of this new area of science is important due to the fact that population-based dietary recommendations are not adequate for all individuals as people respond differently to diets. The public has to be genotyped for specific genetic variations and made aware of their chronic disease risk and nutrient deficiencies, and given detailed tailormade personalised nutrition guidelines to allow a better control of health based on their genotype, age, life stage and gender (Baumler, 2012). For example, in 2007, scientists discovered the gene associated with fat mass and obesity called the FTO. SNP within the FTP gene predispose people to obesity (Fawcett and Barroso, 2010) and when these individuals consumed a diet low saturated fat, their predisposition to obesity was significantly reduced (Baumler, 2012). Low saturated fat palm oil would therefore be an ideal oil to be consumed by genotype predisposed individuals to obesity.

\section{MAJOR BREAKTHROUGHS AND COMMERCIALISATION OF NUTRIGENOMICS RESEARCH}

Although nutrigenomics research is still in its infancy, there has been some significant breakthroughs and currently the market is estimated to be worth USD 730 million and is growing by 20\% per annum (Research and Markets, 2010). One of the first success stories in this field is by the company WellGen Inc., USA. This company employed the science of nutrigenomics to study the effects of food ingredients on gene expression that influence human states of health and wellness. In 2007, WellGen was awarded a patent entitled Black Tea Extract for Prevention of Disease (Patent No. $7,238,376)$ that covers, among other things, its proprietary product, WG0401, an enriched extract from black tea for treatment of arthritis, inflammation and cancer. WellGen owners have marketed WG0401 to the nutritional supplement industry, where products for joint health is projected to grow into a billion-dollar industry.

In Europe, the establishment of several European-based consortia (NuGO, Lipgene, Diogenes and IOP Genomics) indicates a huge interest in nutrigenomics (Harttig et al., 2009). These consortia are working with biotechnology companies to develop, produce and commercialise nutrigenomics active ingredients with health benefits aimed at the functional food industry and the nutraceutical market. One such industry is Actigenomics, Switzerland. Their products include Lipistase ${ }^{\mathrm{TM}}$, that reduces LDL cholesterol and triglyceride levels, Immunitum ${ }^{\mathrm{TM}}$ that reinforces the immune system and Dynosteon ${ }^{\mathrm{TM}}$ that restores bone mass and density (http://www. actigenomics.com/applications/products/). The science of nutrigenomics, specifically epigenomics, is also being applied at Nestlé, Switzerland where they have a number of international alliance with researchers at institutions in United Kingdom, New Zealand, Auckland and Singapore. Nestle has contributed a total sum of 18.1 million Euro for this collaborative project and recently filed a patent for infant nutritional product with casein protein to prevent metabolic syndrome disorders later in life (Harrison-Dunn, 2015).

According to the research report by Transparency Market Research (2016), titled Nutrigenomics Market - Global Industry Analysis, Size, Share, Growth, Trends and Forecast 2012 - 2018, other major players in the field of nutrigenomics include BASF, Danone, Unilever, Gene Smart and Geneova Diagnostics. This report also reveals that nutrigenomics products are broadly accepted in North America and in Europe while the Asia Pacific region is expected to witness a huge growth in the coming years.

\section{CONSTRAINTS AND SPECIFIC REQUIREMENTS NEEDED TO CONDUCT NUTRIGENOMICS RESEARCH}

Despite great hope and opportunities of nutrigenomics, there are some major constraints that remain to be addressed. Some of the challenges include the complexity and the difficulty of comprehensive understanding of the genediet interactions as not all individuals respond identically to dietary interventions (CorthésyTheulaz, 2005). Dietary compounds in the gastrointestinal tract are exposed to a number of physical, chemical and microbial modification and the extent of its breakdown and absorption is very much dependent of the physiological health of 
the individual and the profile of microorganisms present in the gut. In carrying out research in nutrigenomics, it is therefore very important to note that all individuals respond differently to the foods they consume. This necessitates a more personalised approach to nutrition for disease prevention and hence, requires a much more comprehensive understanding of nutrient-gene interactions and their impact on phenotype in order to identify, evaluate, and prioritise appropriately targeted strategies for dietary intervention. In addition, nutrigenomics studies do not always give consistent results because a substance being investigated is generally not pure - it is part of a food or diet that contains many different dietary components. In a comprehensive review by Sutton (2007), an ideal nutrigenomic food should have the following attributes: controlled composition, high efficacy, bioavailability of active components, no interaction between food components, nutritionally balanced, a macronutrient (protein, polysaccharide, lipid) composition that can withstand process variations. This list may not be entirely realistic but the challenge is to develop palm oil as a 'designer nutrigenomic food' that is able to fulfil some of the these criteria. The basis of 'designer nutrigenomic food' is to nutritionally enhance palm oil where it is able to down-regulate damaging genes, up-regulate useful genes and/ or over regulate genes to enhance performance for disease management.

\section{CONCLUSION}

Like most plantation industries, palm oil faces many challenges in the future. However, with the emerging science of some nutrigenomics, the knowledge and the tools to meet these challenges already exist. The science of some nutrigenomics can potentially transform palm oil as a 'designer nutrigenomic food' and subsequently is able to position itself at the forefront of the global vegetable oils market.

\section{REFERENCES}

ALBANES, D; HEINONEN, O P; TAYLOR, P R; VIRTAMO, J; EDWARDS, B K; RAUTALAHTI, M; HARTMAN, A M; PALMGREN, J; FREEDMAN, L S; HAAPAKOSKI, J; BARRETT, M J; PIETINEN, P; MALILA, N; TALA, E; LIIPPO, K; SALOMAA, E R; TANGREA, J A; TEPPO, L; ASKIN, F B; TASKINEN, E; EROZAN, Y; GREENWALD, P and HUTTUNEN, J K (1996). Alpha-tocopherol and beta-carotene supplements and lung cancer incidence in the alpha-tocopherol, beta-carotene cancer prevention study: effects of base-line characteristics and study compliance. J Natl Cancer Inst., 88: 1560-1570.
AUFFRAY, B (2007). Protection against singlet oxygen, the main actor of sebum squalene peroxidation during sun exposure, using Commiphora myrrha essential oil. Int J Cosmet Sci., 29: 23- 29.

BAI, S K; LEE, S-J; NA, H-J; HA, K-S; HAN, J-A; LEE, H; KWON, Y-G; CHUNG, C-K and KIM, Y-M (2005). Beta-carotene inhibits inflammatory gene expression in lipopolysaccharide-stimulated macrophages by suppressing redox-based NFkappaB activation. Exp Mol Med., 37(4): 323-34.

BAUMLER, M D (2012). Nutrigenetics - building a platform for dietitians to offer personalized nutrition. Today's Dietitian, 14 (9): 48.

BOLSINGER, J; PRONCZUK, A; SAMBANTHAMURTHI, R and HAYES, K C (2014). Anti-diabetic effects of palm fruit juice in the Nile rat (Arvicanthis niloticus). J Nutr Sci., 3: e5.1-11.

BYUN, S; LEE, K W; JUNG, S K; LEE, E J; HWANG, M K; LIM, S H; BODE, A M; LEE, H J and DONG, Z (2010). Luteolin inhibits protein kinase $\mathrm{C} \varepsilon$ and c-Src activities and UVB-induced skin cancer. Cancer Res. 70 (6): 2415-2423.

CHARLTON-MENYS, $\mathrm{V}$ and DURRINGTON, P $N$ (2007). Squalene synthase inhibitors: clinical pharmacology and cholesterol-lowering potential. Drugs, 67: 11-16.

CHE ANISHAS, C I; KARUPAIAH, T; SUNDRAM, K; TAN, Y A; BALASUNDRAM, N; LEOW, S-S; NURRUL, $S \mathrm{~N}$ and SAMBANTHAMURTHI, $\mathrm{R}$ (2014). Oil palm phenolics and vitamin $\mathrm{E}$ reduce atherosclerosis in rabbits. J Funct Food, 7: 541-550.

CHOO, Y M; LAU, H L N; PUAH, C W; NG, M H; BONG, S C; MA, A N and YUSOF, B (2002). Production of phytonutrients (carotenes, vitamin E, sterols, squalene, coenzyme $\mathrm{Q}_{10}$ and phospholipids) from palm methyl esters. MPOB Information Series No. 348 .

CHOUDHURY, N; TAN, L and TRUSWELL, A S (1995). Comparison of POo and olive oil: effects on plasma lipids and vitamin E in young adults. Am J Clin Nutr., 61: 1043-1051.

CORTHÉSY-THEULAZ, I; DEN DUNNEN, J T; FERRE, P; GEURTS, J M W ; MÜLLER, M; BELZEN, N V and OMMEN, B V (2005). Nutrigenomics: the impact of biomics technology on nutrition Research. Ann Nutr Metab., 49: 355-365.

DI MASCIO, P; KAISER, S and SIES, H (1989). Lycopene as the most efficient biological carotenoid singlet oxygen quencher. Arch Biochem Biophys., 274: $532-538$ 
FATTORE, E and FANELLI, R (2013). Palm oil and palmitic acid: a review on cardiovascular effects and carcinogenicity. Int J Food Sci Nutr., 64: 648-659.

FAWCETT, K A and BARROSO, I (2010). The genetics of obesity: FTO leads the way. Trends Genet., 26(6): 266-274.

FERNANDEZ-AYALA, D J M; GUERRA, I; JIMÉNEZ-GANCEDO, S; CASCAJO, M V; GAVILÁN, A; DIMAURO, S; HIRANO, M; BRIONES, P; ARTUCH, R; DE CABO, R; SALVIATI, L and NAVAS, P (2013). Survival transcriptome in the coenzyme $Q_{10}$ deficiency syndrome is acquired by epigenetic modifications: a modelling study for human coenzyme $\mathrm{Q}_{10}$ deficiencies . BMJ Open 2013;3:e002524. DOI:10.1136/bmjopen-2012-002524.

FLORDELLIS, C; PAPATHANASOPOULO, P; LYMPEROPOULOS, A; MATSOUKAS, J and PARIS, H (2007). Emerging therapeutic approaches multi-targeting receptor tyrosine kinases and $\mathrm{g}$ protein-coupled receptors in cardiovascular disease. Cardiovasc Hematol Agents Med Chem, 5(2): 133-145.

FRAZER, KA (2012). Decoding the human genome. Genome Res., 22: 1599-1601.

GOH, S H; CHOO, Y M and ONG, S H (1985). Minor constituents of palm oil. J. Amer. Oil Chem Soc., 62: 237-240

GERSTER, H (1997). The potential role of lycopene for human health. J Am Coll Nutr., 16: 109-126.

GIAMPIERI, F; ALVAREZ-SUAREZ, J $\mathrm{M}$ and BATTINO, M (2014). Strawberry and human health: effects beyond antioxidant activity. J Agric Food Chem., 62 (18): 3867-3876.

GRAEFE, E U; WITTIG, J; MUELLER, S; RIETHLING, A K; UEHLEKE, B; DREWELOW, B; PFORTE, H; JACOBASCH, G; DERENDORF, H and VEIT, M(2001). Pharmacokinetics and bioavailability of quercetin glycosides in humans. J Clin Pharmacol., 41: 492-499.

GRONEBERG, D A (2005). Coenzyme Q10 affects expression of genes involved in cell signalling, metabolism and transport in human CaCo-2 cells. The Intern J Biochem Cell Biol., 37: 1208-1218.

HALLIWELL, B; RAFTER, J and JENNER, A (2005). Health promotion by flavonoids, tocopherols, tocotrienols, and other phenols: direct or indirect effects? Antioxidant or not? Am J Clin Nutr., 81: 268S-276S.

HARRISON- DUNN, A-R (2015). Nestle files casein infant formula patent for better insulin sensitivity. http: / / www.nutraingredients.com / Research / Nestle-files-casein-infant-formula-patent-for-betterinsulin-sensitivity, accessed on 14 March 2016.

HARTTIG, U; TRAVIS, A J; ROCCA-SERRA, P; RENKEMA, M; VAN OMMEN, B and BOEING, H. (2009). Owner controlled data exchange in nutrigenomic collaborations: the NuGO information network. Genes Nutr., 4(2):113-22.

HEBER, D (2008). Multitargeted therapy of cancer by ellagitannins. Cancer Lett., 269: 262-268.

HEIM, K; TAGLIAFERRO, A and BOBILYA, D (2002). Flavonoid antioxidants: chemistry, metabolism and structure-activity relationships. J Nutr Biochem., 13: 572-584.

JAGANATH, I B (2005). Dietary Flavonoids: Bioavailability and Biosynthesis. Ph.D thesis, University of Glasgow. 216 pp.

JAGANATH, I B and ALIZAH, Z (2014). Agri-nutrigenomics - the pharmacy for disease prevention. Buletin Teknologi MARDI, 6: 83-89.

JANG, M; CAI, L; UDEANI, G O; SLOWING, K V; THOMAS, C F; BEECHER, C W; FONG, H H; FARNSWORTH, N R; KINGHORN, A D; MEHTA, R G; MOON, R C and PEZZUTO, J M (1997). Cancer chemopreventive activity of resveratrol, a natural product derived from grapes. Science, 275 (5297): 218-220

KANNAPPAN, R; GUPTA, S C; KIM, J H and AGGARWAL, B B (2012). Tocotrienols fight cancer by targeting multiple cell signaling pathways. Genes and Nutrition, 7 (1): 43-52.

KAPUT, J and RODRIGUEZ, R L (2004). Nutritional genomics: the next frontier in the postgenomic era. Physiol Genomics, 16: 166-177.

KEIJER, J; BUNSCHOTEN, A; PALOU, A and FRANSSEN-VAN HAL, N L W (2005). Beta-carotene and the application of transcriptomics in riskbenefit evaluation of natural dietary components. Biochim Biophys Acta, 1740(2): 139-146.

KONSTANTINIDOU, V; MUÑOZ-AGUAYO, D; KHYMENETS, O; DE LA TORRE, R; SAEZ, G; TORMOS MDEL, C; TOLEDO, E; MARTI, A; RUIZGUTIÉRREZ, V; RUIZ MENDEZ, M V and FITO, M (2010). In vivo nutrigenomic effects of virgin olive oil polyphenols within the frame of the Mediterranean diet: a randomized controlled trial. FASEB J., 24(7): 2546-2557.

KROON, P A; CLIFFORD, M N; CROZIER, A; DAY, A J; DONOVAN, J L; MANACH, C and 
WILLIAMSON, G (2004). How should we assess the effects of exposure to dietary polyphenols in vitro? Amer J Clin Nutr., 80: 15-21.

LEE, S H; TANG, Y Q; RATHKRISHNAN, A; WANG, S M; ONG, K C; MANIKAM, R; PAYNE, B J; JAGANATH, I B and SEKARAN, S D (2013). Effects of cocktail of four local Malaysian medicinal plants (Phyllanthus spp.) against dengue virus 2. BMC Complementary and Alternative Medicine, 13 (1): 192-205.

LEOW, S-S; SEKARAN, S D; TAN, Y A; SUNDRAM, $\mathrm{K}$ and SAMBANTHAMURTHI, R (2013). Oil palm phenolics confer neuroprotective effects involving cognitive and motor functions in mice. Nutr Neurosci., 16(5): 207-217.

LINNEWIEL-HERMONI, K; LINNEWIELHERMONI, K; KHANIN, M; DANILENKO, M; ZANGO, G; AMOSI, Y; LEVY, J and SHARONI, Y (2015). The anti-cancer effects of carotenoids and other phytonutrients resides in their combined activity. Arch Biochem Biophys., 572: 28-35.

LIU, R H (2004). Potential synergy of phytochemicals in cancer prevention: mechanism of action. J Nutr., 134: 3479S-3485S.

MAY, C Y and NESARETNAM, K (2014). Research advancements in palm oil nutrition. Eur J Lipid Sci Technol., 116: 1301-1315.

MEAD, M N (2007). Nutrigenomics: the genomefood interface. Environ Health Perspect., 115(12): A582-A589.

MERTENS-TALCOTT, $S \mathrm{U}$; TALCOTT, $\mathrm{S} \mathrm{T}$ and PERCIVAL, S S (2003). Low concentrations of quercetin and ellagic acid synergistically influence proliferation, cytotoxicity and apoptosis in MOLT-4 human leukemia cells. J Nutr., 133: 2669-2674.

MOHD WAZNUL, A M Z; SHAZWAN A S; MACHAP, C; SITI MARYAM, O; RAHINIZA, K and JAGANATH, I B (2014). Expression profiling of diabetes-related genes in streptozotocin-induced rat after treatment with herbal mixture extract. Paper presented at the International Sciences, Technology \& Engineering 2014. Akademi Koreksional Malaysia, Langkawi, Malaysia.

MOZZON, M; PACETTI, D; FREGA, N G and LUCCI, P (2015). Crude palm oil from interspecific hybrid Elaeis oleifera $\times$ E. guineensis: alcoholic constituents of unsaponifiable matter. J. Amer. Oil Chem. Soc., 92 (5): 717-724.

MUKHERJEE, S and MITRA, A (2009). Health effects of palm oil. J. Human Ecology, 26(3): 197-203.
MULLEN, W; BOITIER, A; STEWART, A J and CROZIER, A (2004). Flavonoid metabolites in human plasma and urine after the consumption of red onions: analysis by liquid chromatography with photodiode array and full scan tandem mass spectrometric detection. J Chromatogr A., 1058: 163168.

MUTCH, D V; WAHLI, W and WILLIAMSON, $G$ (2005). Nutrigenomics and nutrigenetics: the emerging faces of nutrition. The FASEB J., 19(12): 1602-1616.

NESARETNAM, K; GUTHRIE, N; CHAMBERS, A $\mathrm{F}$ and CARROLL, K K (1995). Effect of tocotrienols on the growth of a human breast cancer cell line in culture. Lipids, 30:1139-1143.

NESARETNAM, K; MEGANATHAN, P; VEERASENAN, S and SELVADURAY, K R (2012). Tocotrienols and breast cancer: the evidence to date. Genes Nutr., 7(1): 3-9.

OGUNTIBEJU, O O; ESTERHUYSE, A J and TRUTER, E J (2009). Red palm oil: nutritional, physiological and therapeutic roles in improving human wellbeing and quality of life. Br J Biomed Sci., 66(4): 216-22.

PAN, M H and HO, C T (2008). Chemopreventive effects of natural dietary compounds on cancer development. Chem Soc Rev., 37(11): 2558-2574.

RAPOLA, J M; VIRTAMO, J; RIPATTI, S; HUTTUNEN, J K; ALBANES, D; TAYLOR, P R and HEINONEN, O P (1997). Randomised trial of alpha-tocopherol and beta-carotene supplements on incidence of major coronary events in men with previous myocardial infarction. Lancet, 349: 17151720.

RESEARCH and MARKETS (2010). The nutrigenomic testing marketing market. http://www. businesswire.com/news / home/20100407006731/ en / Research-Markets-Nutrigenomic-TestingMarketing-Market-Estimated, accessed on 14 March 2016.

RICE, A L and BURNS, J B (2010). Moving from efficacy to effectiveness: red palm oil's role in preventing vitamin A deficiency. J Amer Nutr., 29 (3): 302S-313S.

RUTH, L and WRICK, K L (2005). Nutrigenomics: impact on diets, markets and health. Adv Life Sci Rep., 48: 1-261.

SAMBANTHAMURTHI, R; TAN, Y A and SUNDRAM, K (2008). Treatment of vegetation 
liquors derived from oil-bearing fruit. United States patent US 7,387,802 B2.

SAMBANTHAMURTHI, R; TAN, Y A; SUNDRAM, K; HAYES, K C; ABEYWARDENA, M; LEOW, S S; SEKARAN, S D; SAMBANDAN, T G; RHA, C; SINSKEY, A J; SUBRAMANIAM, K; FAIRUS, S and WAHID, M B (2011a). Positive outcomes of oil palm phenolics on degenerative diseases in animal models. Br J Nutr., 106(11): 1664-1675.

SAMBANTHAMURTHI, R; TAN, Y A; SUNDRAM, K; ABEYWARDENA, M; SAMBANDAN, T G; RHA, C; SINSKEY, A J; SUBRAMANIAM, K; LEOW, S S; HAYES, K C and WAHID, M B (2011b). Oil palm vegetation liquor: a new source of phenolic bioactives. Brit J Nutri., 106(11): 1655-1663.

SCHMELZE, C; SCHMELZER, C; NIKLOWITZ, P; OKUN, J G; HAAS, D; MENKE, T and DÖRING, $F$ (2011). Ubiquinol-induced gene expression signatures are translated into altered parameters of erythropoiesis and reduced low density lipoprotein cholesterol levels in humans. Life, 63(1): 42-48.

STOVER, P J (2004). Nutritional genomics. Physiological Genomics, 16 (2): 161-165.

SPENCER, J P; RICE-EVANS, C and WILLIAMS, R J (2003). Modulation of pro-survival akt/protein kinase $B$ and ERK1/2 signaling cascades by quercetin and its in vivo metabolites underlie their action on neuronal viability. J Biol Chem., 278:3478334793.

SUNDRAM, K; SAMBANTHAMURTHI, $\mathrm{R}$ and TAN, Y A (2003). Palm fruit chemistry and nutrition. Asia Pacific J Clin Nutr., 12: 355-362.

SUTTON, K (2007). Considerations for the successful development and launch of personalised nutrigenomic foods. Mutation research. Fundamental Molecular Mechanisms and Mutagenesis, 622(1-2): 117121.
THANGAPAZHAM, R L; SHARMA, $\mathrm{A}$ and MAHESHWARI, R K (2006). Multiple molecular targets in cancer chemoprevention by curcumin. AAPS J., 8 (3): E443-E449.

TRANSPARENCY MARKET RESEARCH (2016). Nutrigenomics market - global industry analysis, size, share, growth, trends and forecast 2012 - 2018. http: / / www.transparencymarketresearch.com/ nutrigenomics-market.html, accessed on 14 March 2016.

VOON, P T; NG, T K W; LEE, $\mathrm{V} \mathrm{K} \mathrm{M}$ and NESARETNAM, K (2011). Diets high in palmitic acid (16: 0$)$, lauric and myristic acids (12: 0 p14: 0 ), or oleic acid (18: 1) do not alter postprandial or fasting plasma homocysteine and inflammatory markers in healthy Malaysian adults. Am J Clin Nutr., 94: 14511457.

WANG, J; BI, W; CHENG, A; FREIRE, D; VEMPATI, P; ZHAO, W; GONG, B; JANLE, E M; CHEN, T Y; FERRUZZI, M G; SCHMEIDLER, J; HO, L and PASINETTI, G M (2014). Targeting multiple pathogenic mechanisms with polyphenols for the treatment of Alzheimer's disease-experimental approach and therapeutic implications. Front Aging Neurosci., 6: 42.

WILLIAMS, R J; SPENCER, J P E and RICE-EVANS, C (2004). Flavonoids: antioxidants or signalling molecules? Free Rad Biol and Med., 36: 838-849.

WILLIAMSON, G and MANACH, C (2005). Bioavailability and bioefficacy of polyphenols in humans. II. Review of 93 intervention studies. Am J Clin Nutr., 81: 243S-255S.

ZEB, A and MEHMOOD, S (2004). Carotenoids contents from various sources and their potential health applications. Pakistan J. Nutrition, 3 (3): 199204. 